\title{
Identifikasi Dan Analisis Kadar Total Partikulat Debu Dari Emisi Cerobong Industri Di Lampung
}

\author{
Identification And Analysis Of Total Particulate Matter From Industry Chimneys \\ Emission In Lampung
}

\author{
Masmulki Daniro Jyoti ${ }^{1)}$ dan Ira Setiawati2) \\ 1)Balai Riset dan Standardisasi Industri Bandar Lampung \\ Jl by pass Soekarno Hatta KM 1 Rajabasa \\ ${ }^{2}$ Balai Besar Kimia Kemasan, Jl Balai Kimia No 1, Jakarta, Indonesia, 13710 \\ E-mail: daaniiroo@gmail.com
}

\begin{abstract}
Abstrak
Perkembangan industri di Provinsi Lampung semakin meningkat, namun dapat menimbulkan sisi negatif yaitu pencemaran udara akibat kegiatan industri tersebut. Salah satu bahan pencemar yang dihasilkan adalah partikulat. Konsentrasi total partikulat yang dihasilkan dari emisi cerobong dapat dipengaruhi oleh jenis bahan bakar dan jumlah beban cerobong yang digunakan oleh industri. Tujuan penelitian adalah untuk mendapatkan pola persebaran emisi berupa partikulat selama periode 1 (satu) tahun dari beberapa industri yang tersebar di Provinsi Lampung dan mengetahui konsentrasi maksimum dari total partikulat tersebut. Penelitian ini dilakukan secara eksploratif kuantitatif dan pengambilan contoh total partikulat dilakukan secara purposive sampling. Hasil penelitian menunjukkan bahwa industri pengolahan merupakan lapangan usaha yang paling banyak beroperasi di Provinsi Lampung pada Tahun 2018 dengan nilai presentase sebesar 68,63\%. Hal ini seiring dengan hasil emisi partikulat tertinggi dihasilkan oleh Kabupaten Tulang Bawang dan Kabupaten Lampung Tengah, dengan konsentrasi rata-rata total partikulat sebesar 74,17 mg/ $\mathrm{Nm}^{3}$ dan 72,68 mg/ $\mathrm{Nm}^{3}$.

Kata kunci: total partikulat, emisi, industry, Lampung
\end{abstract}

\begin{abstract}
The development of industry in Lampung Province is increasing, but can cause a negative side, namely air pollution due to the activities of the industry. One of the pollutants produced is particulate matter. The total concentration of particulates generated from chimney emissions can be influenced by the type of fuel and the amount of chimney load used by industry. The purpose of this research is to obtain the distribution pattern of emissions in the form of particulates over a period of 1 (one) year from several industries scattered in Lampung Province and determine the maximum concentration of the total particulates. This research was conducted in a quantitative exploratory manner and the total particulate sampling was carried out by purposive sampling. The results showed that the processing industry is the most operating business field in Lampung Province in 2018 with a percentage of 68.63\%. This is in line with the highest particulate emissions produced by Tulang Bawang Regency and Central Lampung Regency, with an average total concentration of particulates of $74.17 \mathrm{mg} / \mathrm{Nm}^{3}$ and $72.68 \mathrm{mg} / \mathrm{Nm}^{3}$.
\end{abstract}

Keywords: total particulate matter, emissions, industry, Lampung

\section{Pendahuluan}

Sektor industri pengolahan merupakan salah satu sektor yang berpengaruh signifikan terhadap pertumbuhan ekonomi di Provinsi Lampung (Isnaini, 2019). Hal ini mengakibatkan perkembangan industri di Provinsi Lampung semakin meningkat. Menurut data hasil sensus ekonomi Badan Pusat Statistik (BPS) pada tahun 2016, jumlah usaha dan perusahaan di Provinsi
Lampung menempati posisi kedua terbesar di Sumatera setelah Sumatera Utara, dengan jumlah total Usaha Mikro Kecil (UMK) dan Usaha Menengah Besar (UMB) sebanyak 777.060. Jenis-jenis industrinya pun beraneka ragam yang tersebar ke dalam 13 kategori usaha diantaranya kategori pertambangan, energi, pengelolaan air dan limbah, industri pengolahan, dan konstruksi (Badan Pusat Statistik, 2016. 
Salah satu peralatan yang mendukung kegiatan industri tersebut adalah boiler yang berfungsi untuk menghasilkan steam dengan cara memanaskan air hingga menjadi uap. Untuk menghasilkan steam ataupun panas, boiler membutuhkan energi yang berasal dari bahan bakar seperti minyak solar, biomassa padat, batubara, ataupun gas alam, tergantung pada rancang proses dan keperluan industrinya (Komariah et.al, 2014). Proses pembakaran dengan boiler akan menghasilkan polutan berupa emisi gas buang yang dikeluarkan cerobong. Emisi udara yang dikeluarkan tersebut umumnya mengandung bahan pencemar berupa partikulat (debu), ataupun berupa gas seperti $\mathrm{NO}_{2}$ dan $\mathrm{SO}_{2}$. Bahan pencemar tersebut umumnya bersifat sangat toksik, mudah bereaksi dan menyebar sesuai arah angin yang dapat mencemari lingkungan (Sugiarto et.al, 2019; Rahmadhani et.al, 2017).

Emisi pencemaran udara oleh industri sangat tergantung dari jenis industri dan prosesnya, peralatan industri dan utilitasnya (Ratnani, 2008). Jumlah polutan yang dipancarkan ke luar kawasan industri juga dapat dipengaruhi oleh jenis dan kapasitas bahan bakar serta ketinggian stack yang digunakan oleh industri (Ruhiat dkk 2017). Hasil penelitian Sugiarto et.al (2019) diperoleh bahwa pada industri pengolahan kelapa sawit yang sama namun menggunakan bahan bakar boiler yang berbeda akan menghasilkan konsentrasi partikulat yang berbeda. Boiler dengan bahan bakar batubara menghasilkan konsentrasi partikulat lebih tinggi daripada boiler dengan bahan bakar cangkang kelapa sawit.

Oleh karena Provinsi Lampung memiliki beragam jenis industri, maka penelitian ini bertujuan untuk mendapatkan pola persebaran emisi berupa partikulat yang dihasilkan dari berbagai jenis industri di Provinsi Lampung dan mengetahui konsentrasi maksimum dari total partikulat tersebut. Hasil yang diperoleh diharapkan dapat digunakan sebagai data dan informasi kepada pihak berwenang mengenai konsentrasi partikulat di industri yang berada di Provinsi Lampung, sehingga dapat melakukan tindakan perbaikan sesuai dengan prosedur yang ditetapkan terhadap hasil yang melebihi persyaratan standar. Selain itu, dengan adanya penelitian ini juga diharapkan dapat mendorong industri-industri di Indonesia khususnya di Provinsi Lampung untuk menerapkan standar industri hijau.

\section{Metodologi Penelitian}

Penelitian ini adalah penelitian
eksploratif kuantitatif dengan cara mengumpulkan informasi mengenai jenis-jenis industri yang beroperasi di Provinsi Lampung dan melakukan evaluasi kadar emisi berupa total partikulat yang dihasilkan oleh cerobongcerobong industri di Provinsi Lampung. Pengambilan contoh dilakukan secara purposive sampling yaitu ditujukan pada data total partikulat emisi dari cerobong-cerobong industri kategori pertambangan, energi, pengelolaan air dan limbah, industri pengolahan, dan konstruksi yang telah diuji oleh Lembaga Inspeksi Teknis Bandar Lampung pada Tahun 2018. Sampel yang diambil sebanyak 51 perusahaan dengan tiap daerah berbeda-beda jumlahnya karena persebaran industri di Provinsi Lampung menyesuaikan kondisi geografisnya.

Pengambilan contoh dan pengujian kadar total partikulat dilakukan sesuai dengan SNI 19-7117.12-2005 (Emisi gas buang Sumber tidak bergerak - Bagian 12: Penentuan total partikel secara isokinetik) dan hasil uji dianalisis secara deskiriptif.

\section{Hasil Dan Pembahasan}

Provinsi Lampung dibagi dalam 15 Kabupaten/Kota dengan rincian sebagai berikut: Kabupaten Lampung Barat, Kabupaten Lampung Selatan, Kabupaten Lampung Tengah, Kabupaten Lampung Timur, Kabupaten Lampung Utara, Kabupaten Mesuji, Kabupaten Pesawaran, Kabupaten Pesisir Barat, Kabupaten Pringsewu, Kabupaten Tanggamus, Kabupaten Tulang Bawang, Kabupaten Tulang Bawang Barat, Kabupaten Way Kanan, Kota Bandar Lampung dan Kota Metro. Pembangunan ekonomi setiap kabupaten/kota sangat dipengaruhi oleh sektor industri sehingga setiap daerah dipacu untuk mendorong perluasan industri. Pertumbuhan yang cepat dari satu atau beberapa industri juga dapat mengakibatkan pengaruh negatif yaitu menghasilkan emisi yang dapat mengurangi kualitas udara di sekitar. 


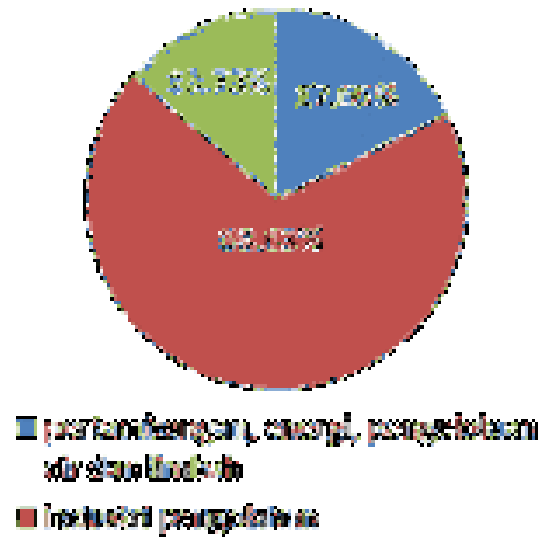

Elaxkedis

Gambar 1. Jumlah industri mayoritas di Provinsi Lampung pada tahun 2018

Perusahaan yang berkembang di Provinsi Lampung sangat beragam di masingmasing kabupaten/kota. Menurut lapangan usahanya, perusahaan di Provinsi Lampung dibagi dalam 13 kategori dengan 3 kategori yang paling mempengaruhi kualitas udara lingkungan yaitu usaha pertambangan, energi, pengolaan air dan limbah, industri pengolahan, dan konstruksi (Badan Pusat Statistik, 2016). Berdasarkan hasil penelitian ini diperoleh persentase dari ketiga jenis usaha tersebut di Provinsi Lampung pada Tahun 2018 dan disajikan oleh Gambar 1. Hasil penelitian menunjukkan bahwa industri pengolahan merupakan lapangan usaha yang paling banyak beroperasi di Provinsi Lampung pada Tahun 2018 dengan nilai 68,63\%.

Industri pengolahan merupakan kegiatan ekonomi atau lapangan usaha di bidang perubahan secara kimia atau fisik dari bahan, unsur, atau komponen menjadi produk baru. Termasuk kategori industri pengolahan adalah unit yang mengubah bahan menjadi produk baru dengan menggunakan tangan, kegiatan maklon atau kegiatan penjualan produk yang dibuat di tempat yang sama dimana produk tersebut dijual dan unit yang melakukan pengolahan bahan-bahan dari pihak lain atas dasar kontrak (Badan Pusat Statistik, 2016). Industri pengolahan yang terdapat di Provinsi Lampung sebagian besar meliputi industri agro seperti tapioka, gula kristal putih, minyak kelapa sawit, dan buah-buahan.

Salah satu kegiatan utama dalam industri pengolahan dalah proses pembakaran. Proses pembakaran menggunakan boiler pada setiap kegiatan tidak selamanya maksimal, sehingga terdapat emisi yang dihasilkan. Bahan pencemar dalam emisi yang paling mempengaruhi kualitas udara adalah partikulat (debu). Selain itu, partikulat merupakan parameter yang selalu ada dalam seluruh peraturan Baku Mutu Emisi yang ada khususnya sumber tidak bergerak (Purwanta, 2018). Oleh karena itu, pentingnya industri pengolahan melakukan pengujian atau pemantauan emisi berupa partikulat.

Data hasil pengujian total partikulat dari beberapa industri yang tersebar di Provinsi Lampung pada Tahun 2018 disajikan dalam Gambar 2.

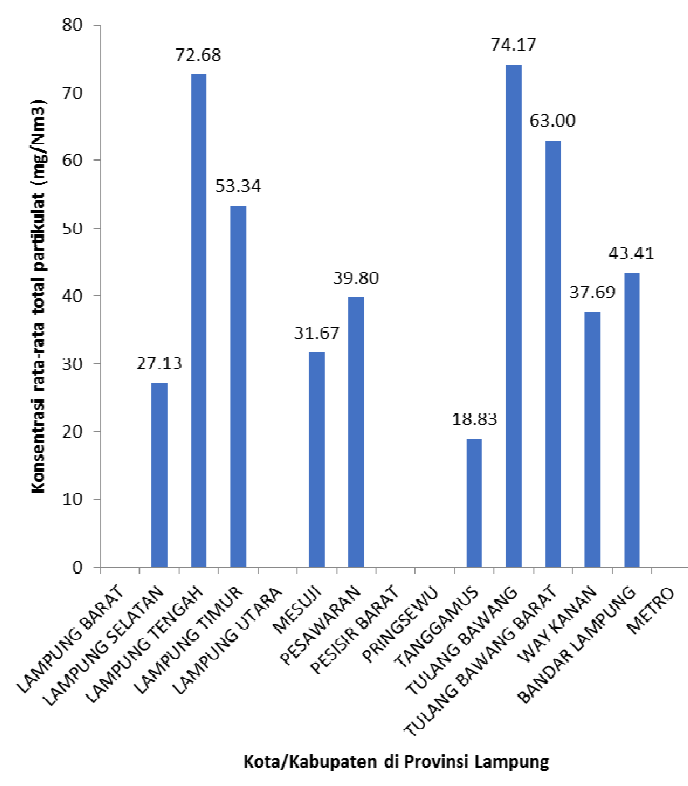

Gambar 2. Konsentrasi rata-rata total partikulat dari emisi cerobong industri di Provinsi Lampung selama periode 1 tahun 2018

Berdasarkan hasil pengujian yang disajikan pada Gambar 2, diketahui bahwa hampir semua kabupaten/kota menghasilkan polutan emisi berupa partikulat. Hal ini menunjukkan bahwa setiap kabupaten/kota terdapat kegiatan industri yang menghasilkan emisi. Namun, beberapa kabupaten/kota tidak menghasilkan emisi partikulat seperti Kabupaten Lampung Barat, Kabupaten Pesisir Barat, Kabupaten Pringsewu, dan Kota Metro. Wilayah geografis dari kabupaten/kota tersebut kurang cocok untuk kegiatan industri pengolahan sehingga tidak ada data konsentrasi total partikulat di daerah tersebut.

Konsentrasi partikulat yang diuji adalah konsentrasi total dan merupakan rata-rata dari beberapa industri yang telah disampling. Nilai konsentrasi yang dihasilkan berbeda-beda pada setiap kabupaten/kota. Besarnya konsentrasi total partikulat tersebut dapat dipengaruhi oleh jenis industri yang beroperasi. Setiap industri 
melakukan proses pembakaran yang menggunakan boiler dengan bahan bakar yang berbeda-beda dan kapasitas yang berbeda-beda, sehingga dihasilkan konsentrasi partikulat yang beragam di setiap kabupaten/kota. Berdasarkan jenis bahan bakar yang digunakan oleh industri, maka hasil yang diperoleh ditunjukkan dalam Gambar 3.

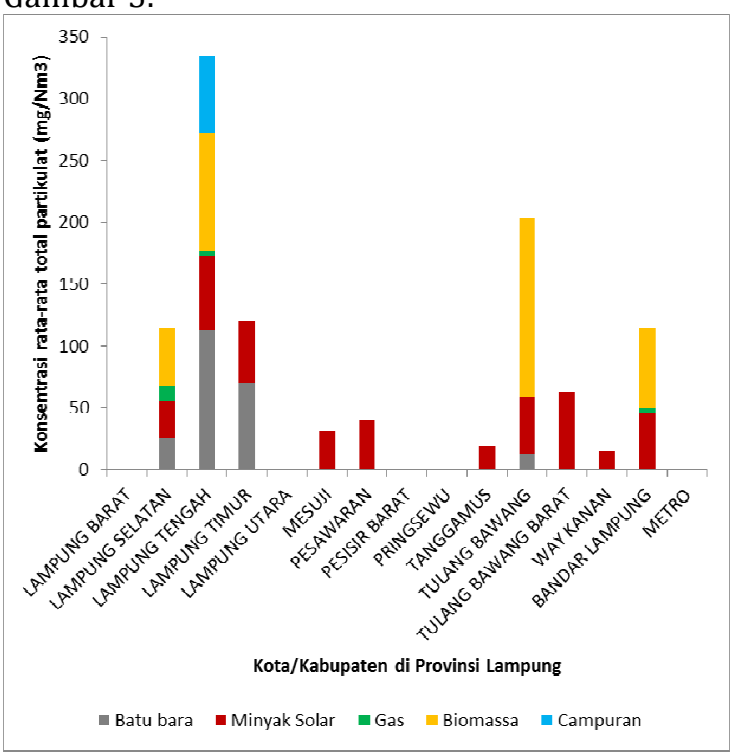

Gambar 3. Konsentrasi rata-rata total partikulat dari emisi cerobong industri di Provinsi Lampung selama periode 1 tahun 2018 berdasarkan jenis bahan bakar yang digunakan

Dari hasil pengujian pada Tahun 2018, konsentrasi rata-rata total partikulat terbesar dihasilkan oleh Kabupaten Tulang Bawang dan Kabupaten Lampung Tengah, ditunjukkan pada Gambar 2 dengan nilai masing-masing sebesar $74,17 \mathrm{mg} / \mathrm{Nm}^{3}$ dan $72,68 \mathrm{mg} / \mathrm{Nm}^{3}$. Salah satu yang mempengaruhi besarnya nilai tersebut adalah jenis bahan bakar yang digunakan. Bahan bakar yang biasa digunakan oleh industri antara lain: batubara, minyak, gas alam, dan biomasa seperti serabut/cangkang sawit, ampas/daun tebu kering (Setiawati dan Jyoti, 2014). Pada Gambar 3 terlihat bahwa total partikulat di Kabupaten Tulang Bawang lebih banyak dihasilkan oleh sumber tidak bergerak dengan bahan bakar jenis biomassa. Sedangkan di Kabupaten Lampung Tengah lebih banyak dihasilkan oleh sumber tidak bergerak dengan bahan bakar batu bara dan biomassa.

Tabel 1. Baku Mutu Emisi Sumber Tidak Bergerak bagi Ketel Uap untuk Parameter Total Partikulat Berdasarkan Jenis Bahan Bakar (Peraturan Menteri Lingkungan Hidup No. 7 Tahun 2007)

Bahan Bakar

\begin{tabular}{lc}
\hline & $\left(\mathrm{mg} / \mathrm{m}^{3}\right)$ \\
\hline Biomassa & 300 \\
Serabut/Cangkang & \\
Biomassa & 250 \\
Ampas/Tebu Kering & 350 \\
Biomassa lain & 230 \\
Batubara & 200 \\
Minyak & \\
\hline
\end{tabular}

Hasil penelitian juga menunjukkan bahwa nilai rata-rata konsentrasi total partikulat emisi yang dihasilkan oleh industri pengolahan di Provinsi Lampung pada Tahun 2018 (berdasarkan Gambar 2) masih berada di bawah baku mutu yang telah ditetapkan oleh Peraturan Menteri Lingkungan Hidup No. 7 Tahun 2007 seperti yang disajikan dalam Tabel 1.

Perbedaan jumlah polutan partikulat yang dihasilkan juga dipengaruhi oleh bentuk partikulat tersebut. Partikulat dalam emisi gas buang terdiri dari bermacam-macam komponen, tidak hanya berbentuk padatan tapi juga berbentuk cairan yang mengendap dalam partikel debu. Pada proses pembakaran, debu terbentuk dari pemecahan unsur hidrokarbon dan setelah proses oksidasi. Dalam debu tersebut terkandung debu sendiri dan beberapa kandungan metal oksida. Dalam kelanjutan proses ekspansi di atmosfir, kandungan metal dan debu tersebut membentuk partikulat. Sebagian benda partikulat keluar dari cerobong pabrik sebagai asap hitam tebal, tetapi yang paling berbahaya adalah butiran-butiran halus sehingga dapat menembus bagian terdalam paru-paru. Namun, partikulat berdasarkan distribusi ukurannya dapat dikendalikan dengan gravity settler/cyclone, fabric hose filter dan electrostatic precipitators (ESP) (Purwanta, 2018; Ratnani, 2008).

Oleh karena itu, setiap industri dapat melakukan penanganan terhadap partikulat emisi yang dihasilkan oleh cerobong boilernya masing-masing sehingga hasil yang dipancarkan ke lingkungan aman dan memenuhi baku mutu emisi yang telah diatur sesuai jenis industrinya. Peningkatan dan modifikasi alat dan metode sangat diperlukan untuk memperbaiki kualitas udara. Selain itu, kesadaran terhadap lingkungan juga sangat diperlukan agar tercipta udara yang bersih dan sehat.

\section{Kesimpulan}

Hasil penelitian menunjukkan bahwa industri pengolahan merupakan lapangan usaha yang paling banyak beroperasi di Provinsi Lampung pada Tahun 2018 dengan nilai 
presentase sebesar 68,63\% dan tersebar hampir di seluruh kabupaten/kota di Provinsi Lampung. Pada penelitian ini, kegiatan industri pengolahan yang menghasilkan emisi berupa partikulat terbanyak terdapat di Kabupaten Tulang Bawang dan Kabupaten Lampung Tengah, dengan konsentrasi rata-rata total partikulat sebesar $74,17 \mathrm{mg} / \mathrm{Nm}^{3}$ dan 72,68 $\mathrm{mg} / \mathrm{Nm}^{3}$. Jenis bahan bakar yang mempengaruhi total partikulat paling besar di kedua Kabupaten yaitu batubara dan biomassa. Hasil emisi total partikulat yang dihasilkan oleh industri pengolahan di Provinsi Lampung masih dibawah baku mutu sesuai Peraturan Menteri Lingkungan Hidup No. 7 Tahun 2007.

\section{Daftar Pustaka}

Badan Pusat Statistik. 2016. "Sensus Ekonomi 2016." Diunduh pada tanggal 21 November 2019.

https://se2016.bps.go.id/umkumb/index.p hp/site?id=18\&wilayah=Lampung

Badan Standardisasi Nasional. 2005. Standar Nasional Indonesia 19-7117.12-2005 (Emisi gas buang - Sumber tidak bergerak Bagian 12: Penentuan total partikel secara isokinetik. Jakarta: Badan Standardisasi Nasional.

Isnaini, M. 2019. "Pengaruh Sektor Pertanian, Sektor Industri Pengolahan dan Sektor Jasa Pendidikan Terhadap Pertumbuhan Ekonomi di Provinsi Lampung dalam Perspektif Ekonomi Islam." Skripsi. Universitas Islam Negeri Raden Intan Lampung: Fakultas Ekonomi dan Bisnis Islam.

Komariah, L. N., Wasito, B. K., Zakaria, M. 2014. "Analisa Emisi NOx pada Boiler Firetube Berbahan Bakar Biodiesel Sawit." Jurnal Teknik Kimia 20 (3): 49-56.

Purwanta, W. 2018. "Pemenuhan Baku Mutu Udara Emisi dan Penanganannya: Tinjauan Atas Polutan Partikulat, NOx dan $\mathrm{SO}_{2}$." Prosiding Seminar Nasional dan Konsultasi Teknologi Lingkungan 2018. Hal. 32-41.

Rahmadhani, A., Hermana J., Assomadi, A.F. 2017. "Pemodelan Dispersi Debu Industri Semen di Kabupaten Tuban Jawa Timur." Jurnal Teknik ITS 6 (2): A472-A475.

Ratnani, R.D. 2008. Teknik Pengendalian Pencemaran Udara yang Diakibatkan oleh Partikel. Momentum 4 (2): 27-32.

Ruhiat, Y., Syafrizal, S. Hidayat, Y. Indrayono, and H. Akbar. 2017. "Estimated contaminated area of air pollutant from industrial in Cilegon." Research Journal of Environmental
Sciences

11

(3):

108-115.

doi:10.3923/rjes.2017.108.115.

Setiawati, I. dan Jyoti, M. D. 2014. Pengaruh Jenis Bahan Bakar Terhadap Konsentrasi $\mathrm{SO}_{2}$ dalam Emisi Gas Buang Ketel Uap pada Industri Lampung. Majalah Teknologi Agroindustri 6 (2): 72-77.

Sugiarto, Herawati, P., Riyanti A. 2019. "Analisis Konsentrasi $\mathrm{SO}_{2}$, NO2 dan Partikulat pada Sumber Tidak Bergerak (Cerobong) Berbahan Bakar Batubara dan Cangkang (Studi Kasus di Kabupaten Muaro Jambi)." Jurnal Daur Lingkungan 2 (1): 21-28. 